\title{
KEKERASAN HATI FIRAUN DALAM KITAB KELUARAN: TINDAKAN PRIBADI ATAU TINDAKAN ALLAH
}

\author{
Sia Kok Sin
}

\section{ABSTRAKSI}

Kekerasan hati Firaun dalam kitab Keluaran merupakan topik perdebatan teologis yang hangat. Permasalahan yang muncul adalah apakah kekerasan hati itu merupakan kehendak bebas Firaun atau "predetermination" Allah. Kekerasan hati Firaun merupakan salah satu persoalan teologis dalam kitab Keluaran. khususnya kalau kekerasan hati itu merupakan akibat dari tindakan Allah yang mengeraskannya. Apakah adil jika Allah yang mengeraskan hati Firaun, la juga yang menghukum Firaun oleh karena kekerasan hati itu? Urutan pemunculan ungkapan "Allah mengeraskan hati Firaun" (Kel. 4:21; 7:3) yang mendahului ungkapan "Hati Firaun berkeras" (Kel. 7:13) atau "Firaun tetap berkeras hati" (Kel. 8:15) menimbulkan kesan bahwa Allah yang pertama-tama mengeraskan hati Firaun dan bukannya tindakan atau pribadi Firaun untuk mengeraskan hatinya. Pemecahan terhadap masalah ini ada pada pertama, penyelidikan ungkapan "Allah mengeraskan Firaun" (Kel. 4:21, 7:3) atau lebih tepatnya "Allah akan mengeraskan hati Firaun itu" muncul dalam bentuk YQTL (imperfect). Bentuk ini menyatakan bahwa memang Allah sedang atau akan membuat hati Firaun keras, tetapi tak menunjuk secara khusus kapan la melakukannya. Kedua, Kel. 3:19 menyatakan bahwa dalam kemahatahuan-Nya Allah telah tahu bahwa raja Mesir atau Firaun akan "mengeraskan hatinya" dengan tidak membiarkan Israel pergi dari Mesir. Firaun hanya akan melepaskan Israel setelah melewati penghukuman yang keras. Ayat ini penting oleh karena menyatakan bahwa Allah telah mengetahui bahwa Firaun akan mengeraskan hatinya. Perihal bahwa Allah juga akan mengeraskan hati Firaun tidak lagi menjadi masalah, oleh karena Firaun sendiri yang memulai mengeraskan hatinya. Tindakan Allah mengeraskan hati Firaun akan menambah kekerasan hati Firaun.

Kata Kunci: kekerasan hati, Firaun, Allah

Kekerasan hati Firaun itu merupakan topik perdebatan teologis. Walter C. Kaiser Jr. membahasnya sebagai salah satu ucapan sulit dalam Perjanjian Lama. ${ }^{1}$ Permasalahan yang muncul adalah apakah kekerasan hati itu merupakan kehendak bebas Firaun atau "predetermination" Allah. ${ }^{2}$ Kekerasan hati Firaun merupakan salah satu persoalan teologis dalam kitab Keluaran, khususnya kalau kekerasan hati itu merupakan akibat dari tindakan Allah yang mengeraskannya. ${ }^{3}$ Tema "kekerasan hati" ini memang dicatat dua puluh kali dalam Keluaran 4-14, namun yang menjadi persoalan 
bahwa dalam bagian ini disebutkan bahwa Allah sendiri yang mengeraskan hati Firaun sebanyak sepuluh kali. ${ }^{4}$ Kitab Keluaran memang mengungkapkan bahwa Firaun berkeras hati (Kel. 7:14, 22:8:15, dll.), tetapi juga diungkapkan bahwa Allah mengeraskan hati Firaun (Kel. 4:21; 7:3; 9:12, dll.). Menjadi persoalan adalah hati Firaun itu menjadi keras, oleh karena ia sendiri yang berkeras hati atau hal itu merupakan akibat dari tindakan Allah yang mengeraskan hatinya.

Biasanya untuk menghindari tuduhan terhadap karakter Allah muncul pendapat bahwa kekerasan hati Firaun dimulai dari tindakan Firaun berkeras hati, lalu ditindaklanjuti oleh Allah dengan mengeraskan hatinya dan akhirnya menyebabkan bahwa hati Firaun semakin keras. ${ }^{5}$ Pendapat ini biasanya diperhadapkan dengan kesulitan urutan pemunculan ungkapan "Allah mengeraskan hati Firaun" (Kel. 4:21; 7:3) yang mendahului ungkapan "Hati Firaun berkeras" (Kel. 7:13) atau "Firaun tetap berkeras hati"(Kel. 8:15). Urutan pemunculan ini menimbulkan kesan bahwa Allah yang pertama-tama mengeraskan hati Firaun dan bukannya tindakan atau pribadi Firaun untuk mengeraskan hatinya.

Ada juga pendapat yang menjelaskan bahwa ungkapan "Allah mengeraskan hati Firaun" merupakan ungkapan idiomatis tentang penolakan batiniah Firaun yang telah sampai pada titik yang tak dapat dibalikkan atau berubah lagi. ${ }^{6}$ Brevard Childs menolak pandangan ini dengan alasan bahwa penafsiran psikologis ini kehilangan inti teologis, karena ungkapan "Allah mengeraskan hati Firaun" menunjuk dengan jelas adanya "a theology of divine causality" .

Beberapa ahli telah membahas topik ini dengan menggunakan beberapa pendekatan, di antaranya:

\section{Pendekatan Kritik Sumber ${ }^{9}$}

Robert R. Wilson menggunakan pendekatan kritik sumber dalam membahas topik ini. Wilson menyelidiki topik ini dengan menyelusuri sumber $\mathrm{Y}$ (Yahwist), E (Elohist) dan $\mathrm{P}$ (Priestly) untuk menemukan kekhasan pembahasan topik ini dalam sumber ini masing-masing. Sumber Yahwist (Kel. 7:14, 8:15, 32; 9:7, 34) menggunakan kata כבד. Allah tidak pernah dijadikan sebagai subyek atau pelaku, tetapi subyeknya adalah hati Firaun atau Firaun itu sendiri. ${ }^{10}$ Sumber Elohist (Kel. 4:21; 10:20, 27) menggunakan kata חזק yang menyebutkan Allah sebagai subyek yang mengeraskan hati Firaun dan hanya dalam Kel. 9:35 kata ini digunakan untuk mengungkapkan kondisi hati Firaun. ${ }^{11}$ Sedangkan sumber Priestly (Kel. 9:12; 11:10; 14:4, 8, 17) menggunakan kata חז di mana Allah merupakan subyek atau pelaku yang mengeraskan hati Firaun.dan dalam Kel. 7:13, 22: 8:15 di mana menggambarkan kekerasan hati Firaun. ${ }^{12}$ 
Sumber Priestly juga menggunakan kata קששה dalam Kel. 7:3 di mana Allah merupakan subyek atau pelaku yang akan mengeraskan hati Firaun. ${ }^{13}$ Selanjutnya Wilson mengamati dua hal dalam kaitan sumber-sumber ini, yaitu pertama, kata כבר tak digunakan dalam sumber-sumber kemudian dan diganti dengan kata קשישה מחז dan kedua, sumber-sumber kemudian cenderung melihat Allah sebagai subyek atau pelaku yang menyebabkan kekerasan hati Firaun. ${ }^{14}$

Wilson juga melihat fungsi motif kekerasan hati ini dalam setiap sumber. Dalam sumber Yahwist motif ini berada dalam akhir kisah tulah yang menunjukkan bahwa walaupun Firaun telah melihat dan mengalami tulah, namun ia tetap mengeraskan hati dan tidak membiarkan umat untuk pergi. ${ }^{15}$ la juga mengungkapkan bahwa dalam sumber Yahwist ini motif kekerasan hati ini menjadi penghubung dan pengikat antara narasi penindasan dan narasi tulah. ${ }^{16}$ Dalam sumber Elohist Wilson melihat bahwa motif kekerasan ini memberikan kesatuan narasi tulah di mana motif ini merupakan penyebab adanya tulah lagi dan menjadi motif untuk Firaun menoolak untuk melepaskan Israel. ${ }^{17}$ Juga Allah dianggap sebagai penyebab kekerasan hati Firaun ini. ${ }^{18}$ Dalam sumber Priestly motif kekerasan digunakan dalam kaitan narasi tulah, namun motif ini digunakan dalam menekankan kisah konfrontasi antara Musa dan Firaun. ${ }^{19}$

Memang tulisan Wilson ini menolong bagi mereka yang memegang pendekatan hipotesa dokumen yang mana seseorang dapat menemukan kekhasan dari setiap sumber dalam mengungkapkan motif kekerasan hati ini, tetapi tulisan Wilson tidak memberikan jalan keluar atas persoalan konflik teologis dalam topik kekerasan hati ini.

\section{Pendekatan Teologis-Eksegetis}

Pendekatan ini dapat ditemukan dalam tulisan G.K. Beale. ${ }^{20}$ Memang Beale melakukan penyelidikan eksegetis teks-teks yang berkaitan dengan kekerasan hati Firaun ini, namun penyelidikannya dipengaruhi oleh presuposisinya bahwa Allah itu Mahakuasa, sehingga la berhak melakukan segala hal, termasuk menjadi sumber atau penyebab utama kekerasan hati Firaun. Ungkapan "Allah mengeraskan hati Firaun" dalam Kel. 4:21 dan 7:3 mendahului narasi tulah-tulah, menunjukkan bahwa Allah adalah sumber utama kekerasan hati Firaun ("the Ultimate Cause of Pharaoh's Hardening"). ${ }^{21}$ la mengungkapkan tujuan Allah mengeraskan hati Firaun adalah "Yahweh hardens Pharaoh's heart primarily to create an Israelite Heilgeschichte, necessarily involving an Egyptian Unheilgeschichte - all of which culminates in Yahweh's glory."22 Pengerasan hati Firaun oleh Allah merupakan tindakan yang tak bersyarat ("unconditional") atau tak bergantung pada keputusan Firaun dan semata-mata merupakan 
keputusan Allah. ${ }^{23}$

Tulisan Beale banyak memberikan informasi eksegetis yang baik, namun hasil akhir penyelidikannya ini sangat dipengaruhi oleh presuposisi teologisnya tentang kemahakuasaan dan kedaulatan Allah dalam hidup manusia. Aspek kehendak bebas manusia (Firaun) kurang mendapat tempat, sehingga dapat menimbulkan pertanyaan tentang keadilan Allah. Apakah adil kalau Allah yang merupakan penyebab utama kekerasan hati Firaun juga merupakan Allah yang menghukum Firaun atas kekerasan hati itu?.

\section{Pendekatan konteks sastra dan budaya ${ }^{24}$}

Dorian G. Coover Cox mengangkatkan persoalan keadilan Allah dalam kaitan dengan kekerasan hati Firaun. Dalam kaitan dengan pertanyaan tentang keadilan Allah dalam kaitan kekerasan hati Firaun, Cox menjawab dengan pasti bahwa kitab Keluaran menunjukkan bahwa tuduhan bahwa Allah tidak adil adalah tuduhan yang salah. ${ }^{25}$ Cox menyelidiki topik ini dengan pendekatan yang memperhatikan konteks sastra dan budaya.

Melalui penyelusuran konteks sastra Cox menyelusuri adanya kisahkisah dalam kitab Kejadian dan Keluaran yang mengungkapkan telah adanya ketegangan atau permusuhan antara Allah dan Mesir (Firaun). ${ }^{26}$ Cox memulai dengan kisah Penciptaan yang menunjukkan Allah adalah Pencipta dan Pemilik segala sesuatu, termasuk yang dimiliki oleh Firaun. ${ }^{27}$ Selanjutnya ia mengungkapkan tentang keberadaan keturunan Abraham (Israel) dan penindasan mereka di Mesir yang telah Allah nubuatkan pada masa Abraham (Kej. 15:13-14), ketegangan antara Abraham dan keturunannya dengan raja-raja asing (termasuk Mesir - Kej. 12:10-20) dan kisah Yusuf yang menyelamatkan Mesir. ${ }^{28}$ Dalam kaitan dengan kitab Keluaran, Cox mengungkapkan salah satu tema penting dalam kitab Keluaran adalah melalui segala karya-Nya (termasuk tulah-tulah), Allah ingin manusia mengakui Dia sebagai Tuhan. ${ }^{29}$ Kisah dalam Keluaran tak didasarkan pada masalah etnis, di mana adanya superioritas Israel atas Mesir. ${ }^{30}$ Kekerasan hati Firaun nampak dalam wujud ketidakbersediaannya untuk mengakui Allah sebagai Tuhan dan rencana-Nya untuk membebaskan Israel dari Mesir. ${ }^{31}$ Cox juga mengangkapkan perihal kemarahan Musa terhadap Firaun (Kel.11:8) sebagai dasar bahwa Firaun pun bertanggung jawab atas kekerasan hatinya, walaupun Musa tahu bahwa Allah juga berperan dalam kekerasan hati Firaun. ${ }^{32}$

Sedangkan melalui perhatian terhadap konteks budaya Mesir, Cox mengkontraskan konsep Mesir tentang Firaun sebagai raja yang besar dan kitab Keluaran yang menempatkan Firaun di bawah kekuasaan Allah sebagai Raja yang Besar itu. ${ }^{33}$ Firaun adalah raja yang memberontak atas 
kekuasaan Allah, Sang Raja Besar itu. ${ }^{34}$ Tulah-tulah tak hanya menyerang sistem kepercayaan Mesir, tetapi juga status Firaun. ${ }^{35}$ Cox juga memberikan uraiannya tentang kekerasan hati dalam konteks budaya Mesir yang menunjukkan dalam hati yang ringan akan menikmati hidup kekal, sedangkan hati yang berat menimbulkan masalah besar bagi yang memilikinya. ${ }^{36}$

Dalam bagian kesimpulan dapat ditemukan bahwa secara umum Cox berupaya menyimbangkan kekerasan hati Firaun itu sebagai tindakan yang bersifat alami dan supraalami. ${ }^{37}$ Bersifat alami oleh karena tindakan itu merupakan keputusan pribadi Firaun dan bersifat supraalami oleh karena hal itu juga merupakan karya Allah atas diri Firaun. Oleh karena itu Allah tidak dapat dituduh bahwa la tak adil, oleh karena kekerasan hati Firaun itu juga merupakan keputusan pribadi Firaun. Cox mengungkapkan bahwa jika Allah tidak mengeraskan hati Firaun, Firaun secara hakiki tidak akan berbeda dan perbedaannya hanyalah bahwa mungkin ia hanya akan mengalami tulah yang lebih sedikit. ${ }^{38}$

Menurut penulis bahwa pendekatan konteks sastra dan budaya yang dicetuskan oleh Cox, tidaklah memberikan solusi yang berarti atas perdebatan tentang kekerasan hati Firaun. Tulisan Cox hanya memberikan informasi tambahan dalam melihat perdebatan ini dalam persektif yang lain, tapi belum memberikan solusi yang baik.

\section{Pendekatan Kritik Narasi}

Dalam membahas topik ini David M. Gunn menggunakan pendekatan kritik narasi yang memberikan perhatian pada plot dan karakter Keluaran 1$14 .^{39}$ la mengungkapkan "Plot implies action, action by characters and actions impinging on characters.... Questions about the cause or motivation of the hardening will therefore rapidly develop into questions about the characters involved."40 Gunn mengungkapkan bahwa Firaun merupakan karakter pemimpin yang bengis. ${ }^{41}$ Hal itu dapat dilihat dalam kisah penolakan Firaun terhadap permintaan Musa untuk mengizinkan Israel mengadakan perayaan bagi Yahweh (Kel. 5:1-9). ${ }^{42}$ Karakter Firaun itu semakin jelas dalam kisah tulah-tulah yang juga mengungkapkan bagaimana ia mengeraskan hatinya dengan tidak memberikan respons yang tepat terhadap tulah-tulah itu dan juga tidak membebaskan Israel. Ketika membahas antara karakter Allah dan Firaun dalam kaitan dengan kekerasan hati Firaun, Gunn mengungkapkan:

"To summarize so far, we can that while in the early stages of the story we are invited to see Pharaoh as his own master, hardening his own heart (perhaps the legacy of the $J$ story), as the narrative develops it becomes crystal clear that God is ultimately the only agent of hearthardening who matters (the Plegacy). "Pharaoh's heart was hardened" 
thus becomes a kind of shorthand for "Yahweh caused Pharaoh's heart to harden." If Pharaoh may been directly responsible for his attitude as the commencement, by the end of the story he is depicted as acting against his own better judgement, a mere puppet of Yahweh. ${ }^{\text {,43 }}$

Jadi dapat dikatakan bahwa Firaun pada awalnya yang mengeraskan hatinya dengan melawan Allah dan dalam perkembangannya Allah berperan aktif mengeraskan hati Firaun, sehingga tak ada lagi pilihan lagi bagi Firaun selain hatinya menjadi semakin keras dalam kendali Allah.

Pendapat Gunn ini dikritik oleh G.K. Beale oleh karena penekanan terhadap peran Allah ("divine casuality") dalam mengeraskan hati Firaun, membebaskan Firaun dari tanggung jawab atas tindakannya. ${ }^{44}$ Bagi penulis kritik Beale agak berlebihan, karena Gunn juga membahas peran Firaun ("human causality") dalam kekerasan hatinya. Dalam tulisannya ini Gunn memberikan perhatian pada adanya perkembangan kekerasan hati Firaun. Kekerasan hati Firaun dimulai dari tindakan Firaun berkeras hati, lalu ditindaklanjuti oleh Allah dengan mengeraskan hatinya dan akhirnya menyebabkan bahwa hati Firaun semakin keras. Pendapat Gunn ini biasanya diperhadapkan dengan kesulitan dengan urutan pemunculan ungkapan "Allah mengeraskan hati Firaun" (Kel. 4:21; 7:3) yang mendahului ungkapan "Hati Firaun berkeras" (Kel. 7:13) atau "Firaun tetap berkeras hati"(Kel. 8:15). Urutan pemunculan ini menimbulkan kesan bahwa Allah yang pertama-tama mengeraskan hati Firaun dan bukannya tindakan atau pribadi Firaun untuk mengeraskan hatinya.

Dalam kaitan dalam upaya pembahasan topik ini, pertama-tama penulis menggunakan tulisan Robert B. Chisholm Jr. yang menyusun ayatayat yang berkaitkan dengan topik ini dalam tiga bagian, yaitu: ${ }^{45}$

\section{Teks yang mengungkapkan Allah sebagai Subyek}

Kel. 4:21 Aku akan mengeraskan hatinya

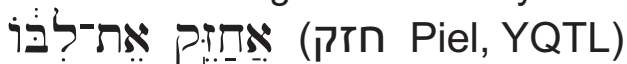

Kel. 7:3 Aku akan mengeraskan hati Firaun

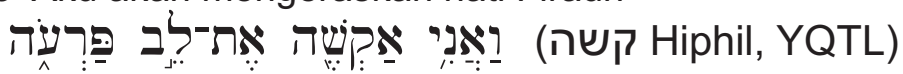

Kel. 9:12 TUHAN mengeraskan hati Firaun

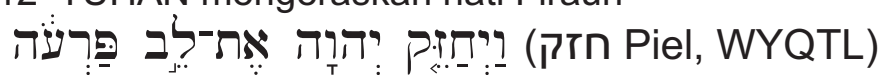

Kel. 10:1 Aku telah membuat hatinya dan hati para pegawainya berkeras

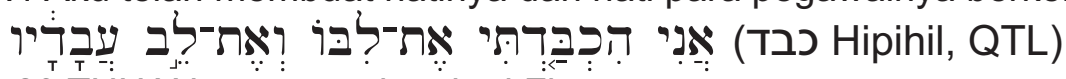

Kel. 10:20 TUHAN mengeraskan hati Firaun

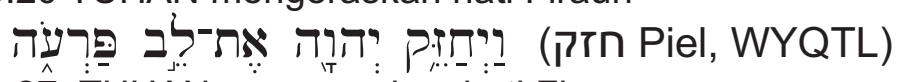

Kel. 10:27 TUHAN mengeraskan hati Firaun

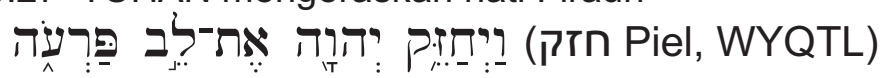


Kel. 11:10 TUHAN mengeraskan hati Firaun

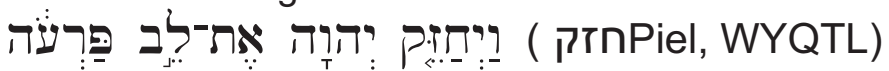

Kel. 14:4 Aku akan mengeraskan hati Firaun

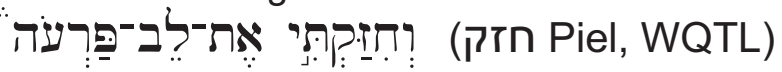

Kel. 14:8 TUHAN mengeraskan hati Firaun

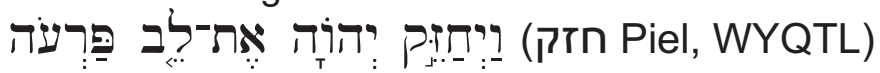

Kel. 14:17 Aku akan mengeraskan hati orang Mesir

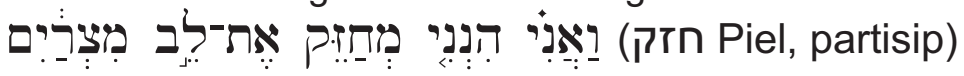

Teks yang mengungkapkan Firaun sebagai subyek

Kel. 8:15 la tetap berkeras hati (TB)

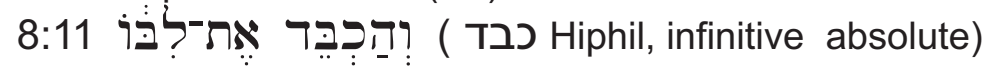

Kel. 8:32 Firaun tetap berkeras hati

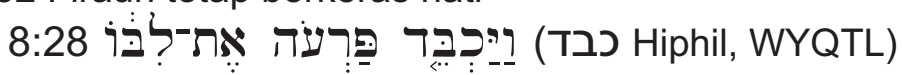

Kel. 9:34 la tetap berkeras hati, baik ia maupun para pegawainya

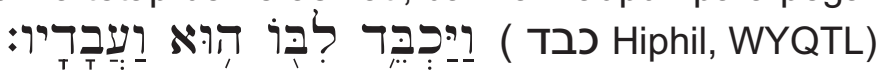

Kel. 13:15 Sebab ketika Firaun dengan tegar menolak untuk membiarkan kita pergi

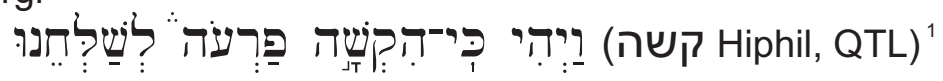

Teks yang mengungkapkan kondisi hati Firaun yang keras

Kel. 7:13 Hati Firaun berkeras

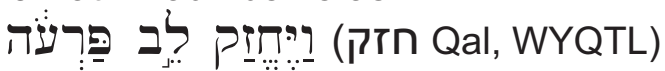

Kel. 7:14 Firaun berkeras hati /Hati Firaun berkeras

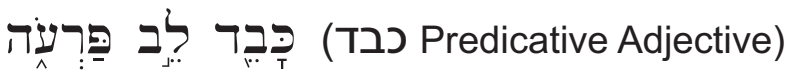

Kel. 7:22 Hati Firaun berkeras

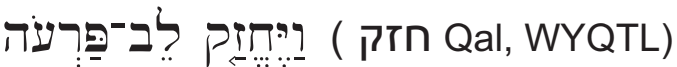

Kel. 8:19 Hati Firaun berkeras

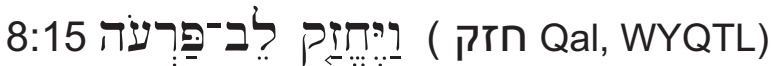

Kel. 9:7 Firaun tetap berkeras hati ${ }^{2}$

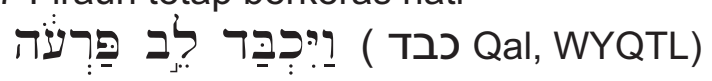

Kel. 9:35 Berkeraslah hati Firaun

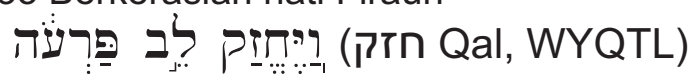

Dari pengamatan sederhana ketiga bagian ini seseorang dapat menyimpulkan bahwa Allah dan Firaun mempunyai peran dalam kekerasan hati ini, karena keduanya menjadi subyek. Allah mempunyai peran dalam kekerasan hati Firaun, oleh karena ungkapan bahwa la mengeraskan hati 
Firaun. Firaun juga mempunyai peran dalam kekerasan hatinya, oleh karena memang adanya ungkapan bahwa ia mengeraskan hatinya. Oleh karena itu pembahasan tentang kekerasan hati Firaun tak dapat melepaskan peran Allah ataupun peran Firaun. Peran Allah dan Firaun ini perlu diselidiki dan ditemukan bagaimana relasi keduanya, sehingga tidak menimbulkan masalah atau konflik teologis yang menganggap Allah tidak adil. Allah dianggap tidak adil, karena Allah yang mengeraskan hati Firaun, la juga yang menghukum Firaun yang berkeras hati.

Dari segi urutan pemunculannya ungkapan tindakan Allah mengeraskan hati Firaun (Kel. 4:21; 7:3) muncul lebih dulu daripada ungkapan hati Firaun menjadi keras (Kel. 7:13) ataupun Firaun mengeraskan hati (Kel. 8:15). Hal ini menimbulkan kesan bahwa Allah yang mengeraskan hati Firuan, sehingga hati Firaun menjadi keras ataupun Firaun mengeraskan hatinya. Kalau Allah merupakan sumber atau penyebab kekerasan hati Firaun, adilkah Allah yang mengeraskan Firaun itu menghukumnya juga?

Kalau sekedar memperhatikan urutan mana yang lebih dulu antara Allah mengeraskan hati Firaun dan hati Firaun menjadi keras atau Firaun mengeraskan hatinya, maka dapat disimpulkan bahwa Allah merupakan penyebab awal kekerasan hati Firaun. Pembacaan teliti kitab Keluaran akan menolong dalam membahas permasalahan ini. Memang Keluaran

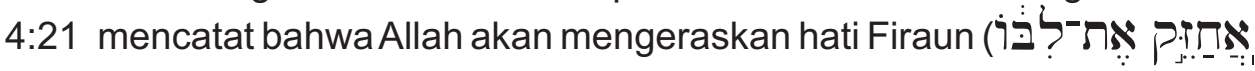

). Kata kerja (קז)( muncul dalam bentuk Piel, YQTL. Bentuk Piel kata kerja ini masuk dalam kategori factitive yang menunjuk pada penyebab yang menghasilkan suatu keadaan. ${ }^{46}$ Bentuk YQTL (Imperfekt) kata kerja ini menunjuk kepada sesuatu yang sedang atau akan terjadi serta tak menunjuk secara spesifik awal atau akhir situasi itu. ${ }^{47}$ Fretheim mengungkapkan hal ini hanya sebagai "promise future action.." ${ }^{\text {. Dalam }}$ Keluaran 7:3 muncul ungkapan "Aku akan mengeraskan hati Firaun"

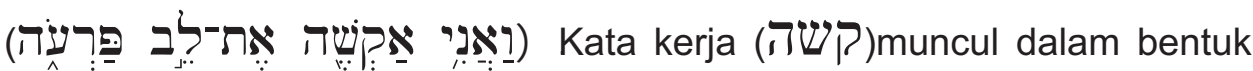
Hiphil, YQTL. Bentuk Hiphil ini dapat dikategorikan dalam factitive yang menunjuk kepada penyebab yang menghasilkan suatu keadaan. ${ }^{49}$ Jadi ayat-ayat ini menyatakan bahwa memang Allah sedang atau akan membuat hati Firaun keras, tetapi tak menunjuk secara khusus kapan la melakukannya. Ayat ini tak memungkiri adanya peranan Allah dalam kekerasan hati Firaun, tetapi ayat ini tak menunjukkan bahwa Allah telah mengeraskan hati Firaun. Allah sedang atau akan menyebabkan hati Firaun keras, tetapi tentang waktunya belum dinyatakan secara pasti. ${ }^{50}$

Ungkapan bahwa Allah telah mengeraskan hati Firaun baru

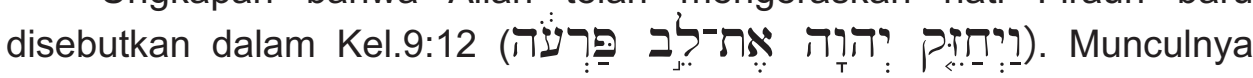
ungkapan ini dalam konteks tulah keenam, berarti Firaun dan orang Mesir 
telah mengalami enam tulah dari Allah. Sedangkan ungkapan "hati Firaun telah menjadi keras" sudah disebutkan dalam Kel. 7:13 dan ungkapan "Firaun mengeraskan hatinya" disebutkan dalam Kel. 8:15. Oleh karena itu dapat diasumsikan bahwa ketika hati Firaun berkembang menjadi keras atau Firaun mulai mengeraskan hatinya, maka Allah mulai bertindak untuk mengeraskan hati Firaun. ${ }^{51}$

Dalam kaitan dengan hal ini, bagian lain yang penting diperhatikan adalah Kel..3:19 yang mengungkapkan: "tetapi Aku tahu bahwa raja Mesir tidak akan membiarkan kamu pergi, kecuali dipaksa oleh tangan yang

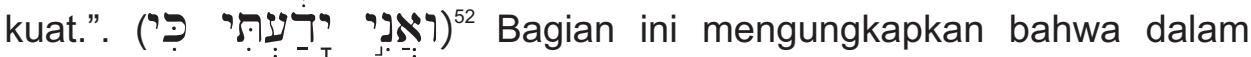
kemahatahuan-Nya Allah telah tahu bahwa raja Mesir atau Firaun akan "mengeraskan hatinya" dengan tidak membiarkan Israel pergi dari Mesir. Firaun hanya akan melepaskan Israel setelah melewati penghukuman yang keras. Ayat ini penting oleh karena menyatakan bahwa Allah telah mengetahui bahwa Firaun akan mengeraskan hatinya. Perihal bahwa Allah juga akan mengeraskan hati Firaun tidak lagi menjadi masalah, oleh karena Firaun sendiri yang memulai mengeraskan hatinya. Tindakan Allah mengeraskan hati Firaun akan menambah kekerasan hati Firaun.

\section{KESIMPULAN}

1. Munculnya ungkapan "Allah mengeraskan Firaun" memang lebih awal dari pada ungkapan Firaun mengeraskan hatinya ataupun hati Firaun menjadi keras, tetapi hal ini tak dapat dijadikan dasar untuk menerima konsep "predetermination" Allah atas kekerasan hati Firaun. Oleh karena ungkapan "Allah mengeraskan Firaun" atau lebih tepatnya "Allah akan mengeraskan hati Firaun itu" muncul dalam bentuk YQTL (imperfect). Bentuk ini menyatakan bahwa memang Allah sedang atau akan membuat hati Firaun keras, tetapi tak menunjuk secara khusus kapan la melakukannya. Ayat ini tak memungkiri adanya peranan Allah dalam kekerasan hati Firaun, tetapi ayat ini tak menunjukkan bahwa Allah telah mengeraskan hati Firaun. Dapat saja dipahami bahwa tindakan Allah mengeraskan hati Firaun seiring dengan tindakan Firaun mengeraskan hatinya. Oleh karena itu tidaklah dapat diterima anggapan bahwa dalam hal ini Allah berlaku membingungkan, oleh karena la yang menjadi perancang kekerasan hati Firaun dan kemudian la menghukum Firaun atas kekerasan hati ini. Pendapat yang mengungkapkan bahwa tindakan Allah mengeraskan hati Firaun seiring dengan tindakan Firaun mengeraskan hatinya, membuat Firaun tetap harus bertanggung jawab dari kekerasan hatinya.

2. Kel. 3:19 merupakan ayat penting dalam kaitan tentang topik kekerasan hati ini. Ayat ini menyatakan bahwa Allah dalam kemahatahuanNya mengetahui bahwa Firaun akan mengeraskan hatinya. Ketika topik ini 
difahami dalam perspektif kemahatahuan Allah dan bukannya kedaulatan Allah yang melakukan "predetermination", maka hal ini tak lagi menjadi masalah atau konflik teologis.

3. Peranan Allah dalam kekerasan hati Firaun tak dapat dihilangkan, tetapi perlu ditempatkan pada proposinya. Tindakan Allah mengeraskan hati Firaun bukanlah penyebab utama kekerasan hati Firaun, tetapi lebih merupakan tindakan penguatan terhadap tindakan Firaun yang telah mengeraskan hatinya. Oleh karena itu tindakan Allah mengeraskan hati Firaun dapat dikatakan merupakan bagian awal atau pendahuluan penghukuman.

\section{End note:}

1. Walter C. Kaiser, Jr., Ucapan Yang Sulit Dalam Perjanjian Lama (Malang: SAAT, 1998), h. 71-73.

2. Scott. M. Langston, Exodus Through the Centuries (Oxford: Blackwell Publishing, 2006), pp. 85-87.

3. Dorian G. Coover Cox, "The Hardening of Pharaoh's Heart in Its Literary and Cultural Contexts," Bibliotheca Sacra 163(July-September 2006), 292.

4. Kaiser, Jr., Ucapan Yang Sulit Dalam Perjanjian Lama, h. 71.

5. Langston mengutip pandangan Origenes yang mengungkapkan bahwa Allah mengeraskan hati orang yang telah berkeras hati, sehingga kekerasan hati itu merupakan sesuatu yang jahat timbul dari dalam orang itu dan bukan merupakan tindakan Allah (predetermination). Exodus Through the Centuries, p. 86.

6. Brevard S. Childs, The Book of Exodus (Louisville: The Westminster Press, 1976), p. 170.

7. Ibid., p. 174

8. Para ahli yang disebutkan dalam bagian ini sebatas kemampuan penulis dalam memperoleh materi. Ada beberapa artikel atau tulisan lain yang membahas topic ini, tetapi penulis tak mampu memperoleh materi tersebut.

9. Robert R. Wilson, "The Hardening of Pharaoh's Heart”, The Catholic Biblical Quarterly, 41, 1979, 18-36.

10. Ibid., 22.

11. Ibid., 23 .

12. Ibid.

13. Ibid.

14. Ibid., 23-24.

15. Ibid., 25.

16. Ibid., 27.

17. Ibid., 29

18. Ibid.

19. Ibid., 30 .

20. G.K. Beale, "An Exegetical and Theological Consideration of The Hardening of Pharaoh's Heart in Exodus 4-14 and Romas 9," Trinity Journal 5 NS (1984), 129-154.

21. Ibid.,133-8, 148-9

22. Ibid. 149.

23. Ibid., 50.

24. Dorian G. Coover Cox, "The Hardening of Pharaoh's Heart in Its Literary and Cultural Contexts," Bibliotheca Sacra 163 (July-September 2006), 292-311.

25. Ibid., 294.

26. Ibid., 294-301.

27. Ibid., 294.

28. Ibid., 294-6.

29. Ibid., 296-7.

30. Ibid., 298.

31. Ibid., 298-300.

32. Ibid., 300-1.

33. Ibid., 301-2.

34. Ibid., 302.

35. Ibid., 303.

36. Ibid., 305-6. 
37. Ibid., 308.

38. Ibid., 311.

39. David M. Gunn, "The 'Hardenng of Pharaoh's Heart': Plot, Character and Theology in Exodus 114," Art and Meaning: Rhetoric in Biblical Literature, ed. David J.A. Clines, David M. Gunn, and J. Hauser, JSOTS 19 (Sheffield: JSOT, 1982), 72-96.

40. Ibid., 74 .

41. Ibid.

42. Ibid.

43. Ibid., 79-80.

44. Beale, "An Exegetical and Theological Consideration...," 300-1.

45. Bagian-bagian ini merupakan pengembangan dari tulisan Robert B. Chisholm Jr., "Divine Hardening in the Old Testament", Bibliotheca Sacra 153 (October-December 1996), 411-2.

46. Ibid., 44.

47. Ibid., 56-57.

48. Fretheim, Exodus, p. 98.

49. Arnold and Choi, A Guide to Biblical Hebrew Syntax, p. 50.

50. Walter C. Kaiser Jr. memahami bagian ini seperti nubuatan para nabi, yang walaupun tak disebutkan persyaratannya. Oleh karena itu ia memahami bahwa Allah tak dapat dipandang sebagai penyebab utama kekerasan hati Firuan. Band. Kaiser, Jr., Ucapan Yang Sulit Dalam Perjanjian Lama, h. 72.

51. Band. Fretheim, Exodus, p. 98.

52. Kata kerjanya dalam bentuk Qal, QTL (perfekt). Penggunaan kata ganti orang pertama sebagai subyek juga menunjuk pada aspek penekanan dalam bagian kalimat ini. 